\title{
Investigation of the Relationship between Reverse Current of Crystalline Silicon Solar Cells and Conduction of Bypass Diode
}

\author{
Hong Yang, He Wang, and Minqiang Wang \\ Institute of Solar Energy MOE Key Laboratory for Nonequilibrium Synthesis and Modulation of Condensed Matter, \\ Department of Physics, Xi'an Jiaotong University, Xi'an 710049, China \\ Correspondence should be addressed to He Wang, hw69cn@126.com
}

Received 9 December 2011; Accepted 31 January 2012

Academic Editor: Bhushan Sopori

Copyright (๑) 2012 Hong Yang et al. This is an open access article distributed under the Creative Commons Attribution License, which permits unrestricted use, distribution, and reproduction in any medium, provided the original work is properly cited.

In the process of crystalline silicon solar cells production, there exist some solar cells whose reverse current is larger than $1.0 \mathrm{~A}$ because of silicon materials and process. If such solar cells are encapsulated into solar modules, hot-spot phenomenon will emerge in use. In this paper, the effect of reverse current on reliability of crystalline silicon solar modules was investigated. Based on the experiments, considering the different shaded rate of cells, the relation between reverse current of crystalline silicon solar cells and conduction of bypass diode was investigated for the first time. To avoid formation of hot spots and failure of solar modules, the reverse current should be smaller than $1.0 \mathrm{~A}$ for $125 \mathrm{~mm} \times 125 \mathrm{~mm}$ monocrystalline silicon solar cells when the bias voltage is at $-12 \mathrm{~V}$.

\section{Introduction}

More and more people are convinced that solar cell technology is the solution for our future energy supply. The crystalline silicon solar cells have been a workhorse of photovoltaic industry for a long time. Although the hotspot endurance tests for extreme outdoor conditions are used for qualification tests procedures, and the bypass diodes are also built in crystalline silicon solar module, hot-spot phenomenon still emerges in solar power plant frequently. This is very detrimental to young photovoltaic industry.

Hot-spot heating in crystalline silicon solar modules occurs when the modules' operating current exceeds the short circuit current of a low-current-producing cell. The reduced short circuit current of cells becomes reverse biased, which leads to power dissipation resulting in the increase in surface temperature [1-3].

In order to avoid hot-spot phenomenon in solar power plant, one of the technical requirements of crystalline silicon solar modules is a fulfilment of the pass criteria of the hot-spot endurance test [4]. But in practice, it is found by infrared camera that the hot-spot heating occurs in some modules even if bypass diodes are built-in. One reason for the hot-spot phenomenon is that some cells have large reverse current in crystalline silicon solar modules. Although some photovoltaic experts have investigated reverse current of crystalline silicon solar cells [5-8], nobody gives a standard that rules magnitude of reverse current in the process of solar modules production from theoretical study or experiments. This question is still under discussion in the photovoltaic area. In this paper, the origin of reverse current is analyzed. Considering the different shaded rate of cells, the relation between reverse current of crystalline silicon solar cells and conduction of bypass diode was investigated for the first time. To avoid formation of hot spots and failure of solar modules, the reverse current should be smaller than $1.0 \mathrm{~A}$ for $125 \mathrm{~mm} \times 125 \mathrm{~mm}$ monocrystalline silicon solar cells when the bias voltage is at $-12 \mathrm{~V}$.

\section{The Origin of Reverse Current for Crystalline Silicon Solar Cells}

Figure 1 shows the reverse bias model and the reverse characteristic of crystalline silicon solar cells. 


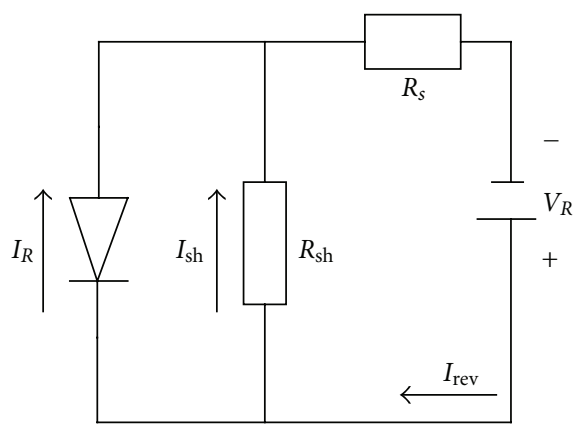

(a) The reverse bias model

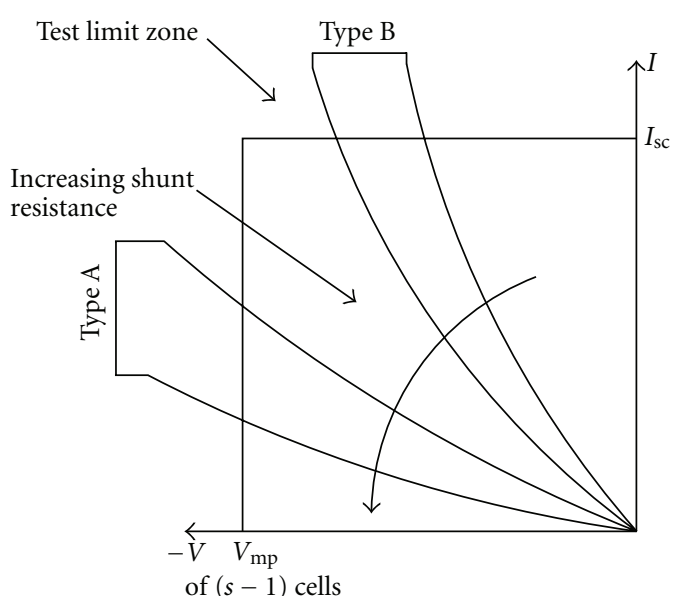

(b) The reverse characteristics

FIgURE 1: The reverse bias model and the reverse characteristic of crystalline silicon solar cells.

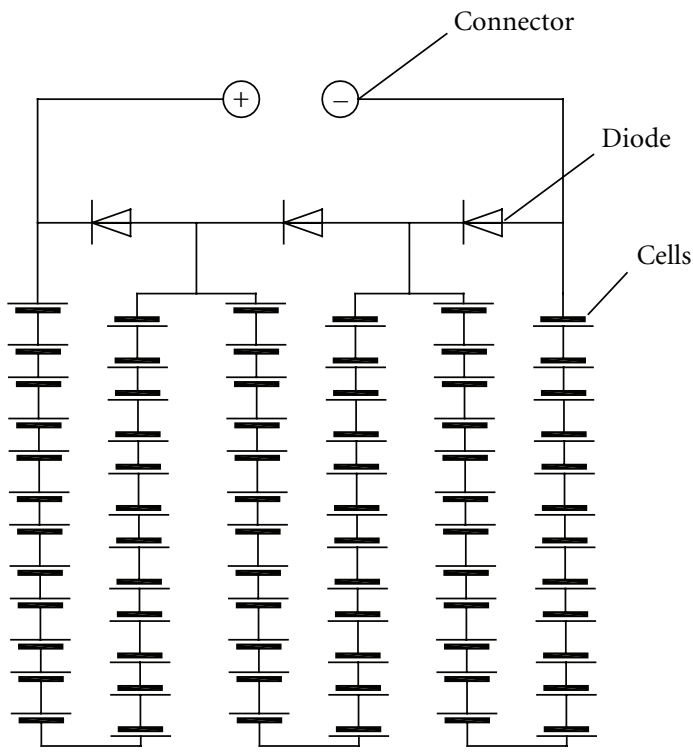

(a) Circuit of solar module

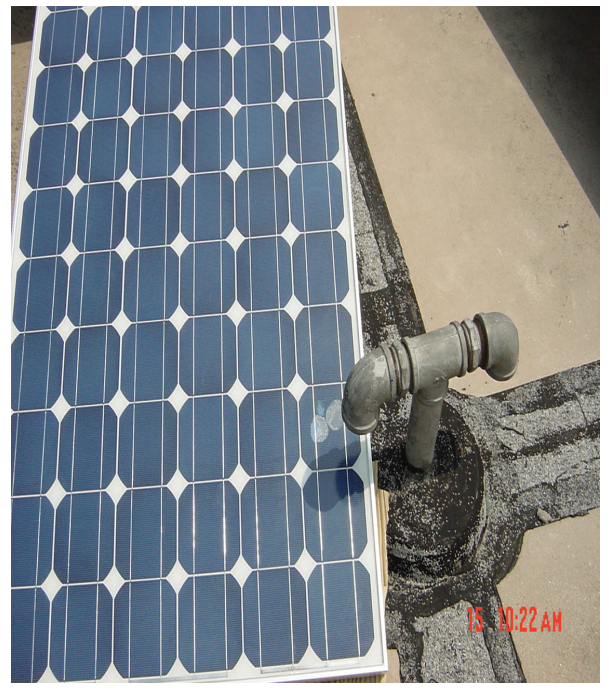

(b) Hot-spot phenomena

FIGURE 2: Hot-spot phenomena of the partially shaded cells.

Figure 1(a), the current flows through the solar cell can be expressed as

$$
\begin{gathered}
I_{\mathrm{rev}}=I_{R}+I_{\mathrm{sh}}=I_{R}+\frac{V_{R}-I_{\mathrm{rev}} R_{S}}{R_{\mathrm{sh}}}, \\
I_{\mathrm{rev}}=I_{0}+\frac{V_{R}-I_{\mathrm{rev}} R_{S}}{R_{\mathrm{sh}}}, \\
I_{\mathrm{rev}}=\frac{I_{0} R_{\mathrm{sh}}}{R_{\mathrm{sh}}+R_{S}}+\frac{V_{R}}{R_{\mathrm{sh}}+R_{S}},
\end{gathered}
$$

where $I_{\text {rev }}$ is the reverse current of crystalline silicone solar cell under reverse bias voltage $V_{R}$ which is below the breakdown voltage of the silicone diode, $I_{R}$ is the reverse leakage current of diode, and $R_{\mathrm{sh}}$ is the shunt resistance.

The P-N junction leakage current $I_{R}$ under reverse bias includes the contributions of diffusion current, space charge generation current; band-to-band tunneling current and thermionic emission current. These shunt types are processed-induced, caused by grown-in defects of the material. The process-induced shunts are due to strong recombination sites at grown-in defects and inversion layers caused by microscopic $(\mathrm{SiC})$ precipitates on grain boundaries [9]. As the reverse bias voltage $V_{R}$ is small, the leakage current $I_{R}$ can be expressed as the function of saturation current of silicon diode $I_{0}$ and shunt resistance $R_{\text {sh }}$. Either the $I_{0}$ increase or $R_{\text {sh }}$ 
TABLE 1: The terminal voltage of the bypass diode.

\begin{tabular}{lccc}
\hline $\begin{array}{l}\text { The reverse current of cells } \\
\text { at bias voltage }-12 \mathrm{~V}\end{array}$ & $\begin{array}{c}\text { Terminal voltage when the } \\
\text { cell is unshaded }(\mathrm{V})\end{array}$ & $\begin{array}{c}\text { Terminal voltage when the } \\
\text { cell is half shaded }(\mathrm{V})\end{array}$ & $\begin{array}{c}\text { Terminal voltage when the } \\
\text { cell is completely shaded }(\mathrm{V})\end{array}$ \\
\hline $0.8 \mathrm{~A}$ & -5.83 & 0.23 & 0.25 \\
$0.9 \mathrm{~A}$ & -5.83 & 0.18 & 0.25 \\
$1.0 \mathrm{~A}$ & -5.83 & 0.15 & 0.25 \\
$1.1 \mathrm{~A}$ & -5.83 & 0.09 & 0.14 \\
$1.2 \mathrm{~A}$ & -5.84 & -0.08 & 0.05 \\
$1.3 \mathrm{~A}$ & -5.82 & -0.09 & -0.24 \\
$1.4 \mathrm{~A}$ & -5.83 & -0.21 & -0.34 \\
$1.5 \mathrm{~A}$ & -5.83 & -0.43 & -0.59 \\
$1.6 \mathrm{~A}$ & -5.84 & -0.58 & -0.83 \\
$1.8 \mathrm{~A}$ & -5.83 & -0.79 & -1.12 \\
2.0 A & -5.82 & -1.03 & -1.25 \\
2.2 A & -5.84 & -1.18 & -1.47 \\
2.4 A & -5.85 & -1.36 & -1.79 \\
2.6 A & -5.83 & -2.63 & -1.83 \\
2.8 A & -5.82 & -3.53 & -1.99 \\
3.0 A & -5.83 & -3.67 & -2.56 \\
\hline
\end{tabular}

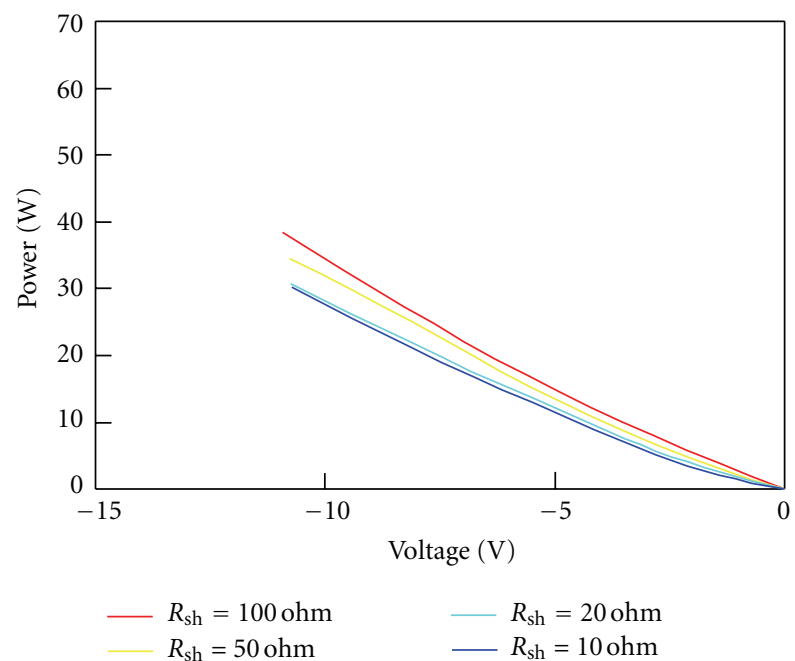

FIGURE 3: The dissipated power at different shunt resistance.

decrease, the reverse current $I_{\text {rev }}$ increases with the variable, and these two parameters determine the solar cell type.

Spirito and Abergamo made a distinction between Atype cells, dominated in reverse bias by avalanche multiplication, and B-type cells, dominated by shunt resistance effects in reverse bias [1]. Reverse bias equation for A-type cells is

$$
\begin{gathered}
I=\left(I_{\mathrm{SC}}-I_{0}\left(\exp \frac{V}{m V_{t}}-1\right)\right) M(V), \\
M=\frac{1}{\left(1-\left(|V| / V_{b}\right)^{n}\right)},
\end{gathered}
$$

where $I_{\mathrm{SC}}, I_{0}, m$ and $V_{t}$ have their usual meaning, $V_{b}$ is breakdown voltage, and $n$ is the Miller exponent.

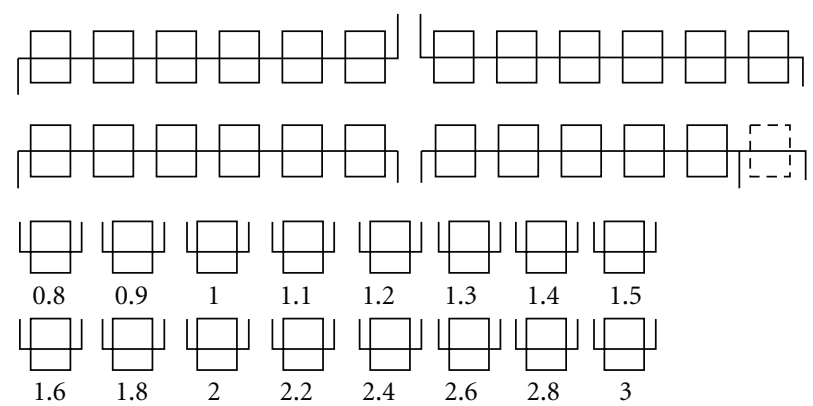

FIgUre 4: The makeup of module before lamination.

In the case of B-type cells, the equation used by the authors is

$$
I=\left(I_{\mathrm{SC}}-I_{0}\left(\exp \frac{V}{m V_{t}}-1\right)\right)-\frac{V}{R_{\mathrm{sh}}} .
$$

The characteristics of different types of solar cells are described in Figure 1(b). The reverse I-V characteristics of the individual cells mainly determine the power dissipated within a single cell under reverse bias.

\section{The Effect of Reverse Current on the Reliability of Crystalline Silicon Solar Modules}

In a general way, the reverse current of crystalline silicon solar cells originates in cell defects and impurity centers in the materials and can be represented by a shunt resistance. We chose 71 cells $(125 \mathrm{~mm} \times 125 \mathrm{~mm})$ whose reverse current is smaller than $1.0 \mathrm{~A}$ at $V=-12 \mathrm{~V}$ and the shunt resistance is larger than $20 \Omega$. And one cell has a $2.008 \mathrm{~A}$ of reverse 


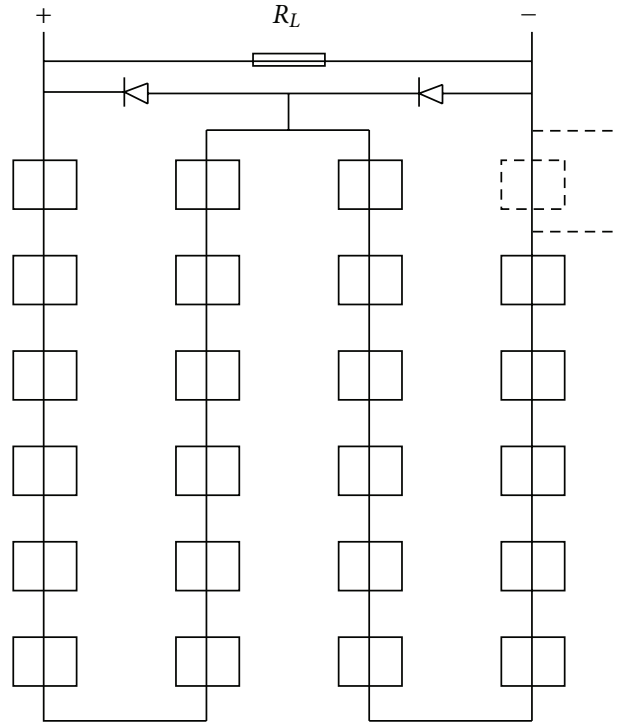

Figure 5: The method of the experiment.

current and $12.88 \Omega$ of shunt resistance. These 72 single silicon solar cells are laminated one module in series that three Schottky diodes are built-in. 24 cells were serially connected with a bypass diode across each string. The modules were short-circuited for several days under natural sunlight; the cell which has a $2.008 \mathrm{~A}$ of reverse current at $-12 \mathrm{~V}$ is partially shaded, and after about $20 \mathrm{kWh} / \mathrm{m}^{2} \cdot$ day of solar irradiation, there was a hot spot in this module, as can be seen from Figure 2.

From Figure 2, this clearly indicates that focal point heating at the hot-spot sites causes irreversible destruction of the crystalline silicon solar module structure, even if bypass diodes were used in this solar module; this is because the shaded cell dissipated power in the form of heat and led to deterioration of the encapsulation.

Figure 3 shows the dissipated power of the shaded cell in a solar module described by Figure 2(a).

As shown in Figure 3, the smaller the shunt resistance is, the more power the shaded cell dissipates.

\section{Investigation of the Threshold of Reverse Current about Bypass Diode Conduction}

In order to study the threshold of reverse current that can avoid hot spot, the experiment designed by us is presented in Figure 4. The cells used in this experiment are $125 \mathrm{~mm} \times$ $125 \mathrm{~mm}\left(154.8 \mathrm{~cm}^{2}\right)$ single crystalline silicon solar cells, and the reverse current of the above two rows of cells is less than $1.0 \mathrm{~A}$ at bias voltage $-12 \mathrm{~V}$. The reverse current of the rest cells is shown in Figure 4.

In Figure 5, the dashed part represents one cell that has different reverse current $(0.8 \mathrm{~A}-3.0 \mathrm{~A})$ and is connected, respectively.

Table 1 gives out the terminal voltage of the bypass diode under different shaded rate.

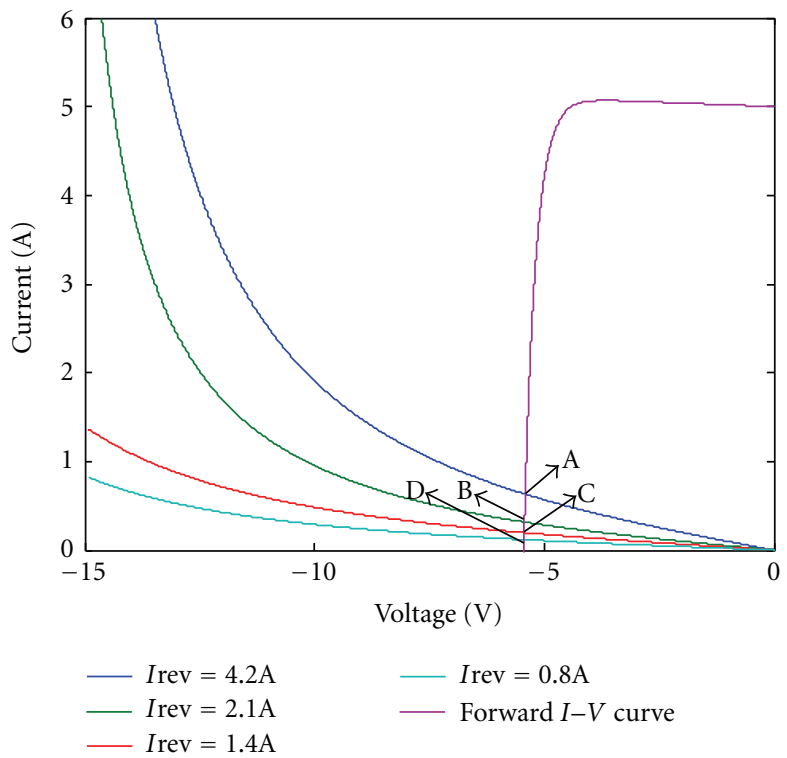

(a) I-V of a cell shaded $75 \%$

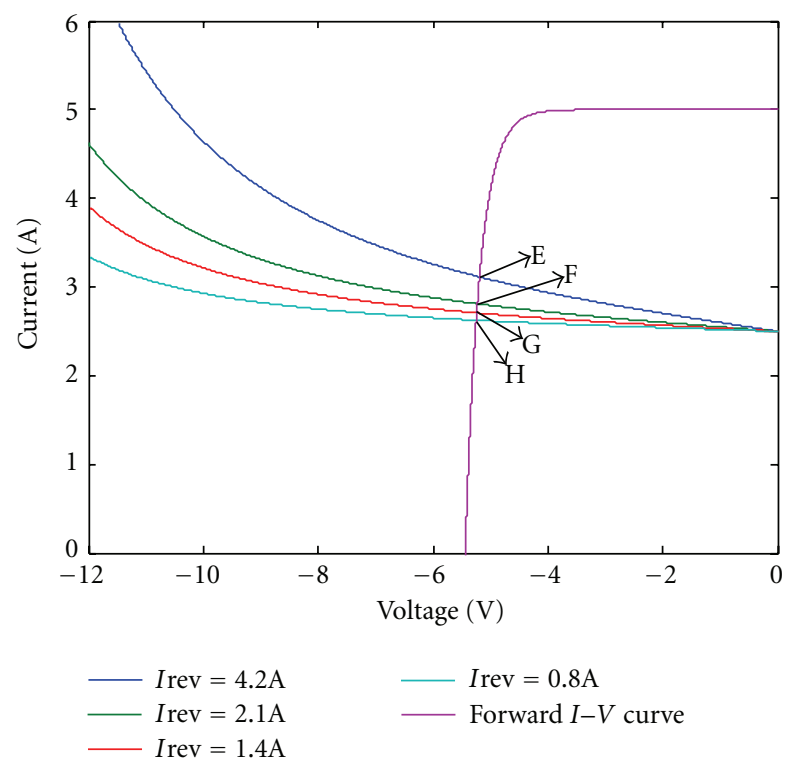

(b) I-V of a cell shaded $25 \%$

FIgure 6: The I-V characteristics of module with a shaded cell.

From Table 1, it can be concluded that the bypass diode becomes conductive easily when the reverse current of solar cells is less than 1.0 A at bias voltage $-12 \mathrm{~V}$, so we can explain why the bypass diode did not function in Figure 2.

By comparing Table 1 with our former experimental results [10], we find that conduction of the bypass diode is also relevant to the area of crystalline silicon solar cell.

Figure 6 gives out the I-V characteristics of shaded photovoltaic module; the current of module is decided by the points of intersection between the reverse I-V of the shaded cells and the forward I-V of the rest cells. 
From this experiment, we find that the larger the reverse current is, the larger the reverse-biased cell dissipates, and it is not more conducive to the bypass diode conduction. The slope of the I-V curve in the reverse bias mode gives information regarding the cell's pn junction properties in shunt resistance and has an effect on the I-V slope of a cell in the reverse bias, resulting in high power dissipation.

For the cells with a large reverse current, in addition to the level of irradiance and reverse current, the dissipated power at a shaded crystalline silicon solar cell is strongly influenced by the shaded rate.

\section{Conclusions}

In general, to avoid of the formation hot spots for crystalline silicon solar modules, substrings of cells inside the interconnection circuit of modules are bridged by bypass diodes, but conduction of bypass diode is determined by the reverse current and the shading rate of the shaded cell.

When the reverse current is larger than $1.0 \mathrm{~A}$ at bias voltage $-12 \mathrm{~V}$ for $125 \mathrm{~mm} \times 125 \mathrm{~mm}$ monocrystalline silicon solar cells, the shaded cell does not become reverse biased and the bypass diode does not conduct; this will lead to irreversible hot-spot damage of cells.

By experiments, we recommended that the reverse current should be smaller than $1.0 \mathrm{~A}$ for $125 \mathrm{~mm} \times 125 \mathrm{~mm}$ monocrystalline silicon solar cells when the bias voltage is at $-12 \mathrm{~V}$.

\section{Acknowledgments}

The authors would like to thank the support of Bureau of Science and Technology under the Project no. CXY 1123 and the fund of Applied Materials Co. of USA under the Project no. 201005. This study was also supported by the Fundamental Research Funds for the Central Universities.

\section{References}

[1] P. Spirito and V. Abergamo, "Reverse bias power dissipation of shadowed or faulty cells in different array configurations," in Proceedings of the 4th European Photovoltaic Solar Energy Conference, pp. 296-300, 1982.

[2] J. Wohlgemuth and W. Herrmann, "Reliability testing for PV modules," in Proceedings of the 26th IEEE Photovoltaic Specialists Conference (PVSC '82), pp. 889-892, 1982.

[3] W. Herrmann, W. Wiesner, and W. Vaassen, "Hot spot investigations on PV modules-new concepts for a test standard and consequences for module design with respect to bypass diodes," in Proceedings of the 26th IEEE Photovoltaic Specialists Conference, pp. 1129-1132, Anaheim, Calif, USA, October 1997.

[4] International Standard IEC-61215:2005, "Crystalline silicon terrestrial photovoltaic (PV) modules design qualification and type approval".

[5] M. C. Alonso-García and J. M. Ruíz, "Analysis and modelling the reverse characteristic of photovoltaic cells," Solar Energy Materials and Solar Cells, vol. 90, no. 7-8, pp. 1105-1120, 2006.
[6] M. C. Alonso-García, W. Herrmann, W. Böhmer, and B. Proisy, "Thermal and electrical effects caused by outdoor hotspot testing in associations of photovoltaic cells," Progress in Photovoltaics: Research and Applications, vol. 11, no. 5, pp. 293-307, 2003.

[7] M. Simon and E. L. Meyer, "Detection and analysis of hot-spot formation in solar cells," Solar Energy Materials and Solar Cells, vol. 94, no. 2, pp. 106-113, 2010.

[8] M. Danner and K. Buecher, "Reverse characteristics of commercial silicon solar cells - impact on hot spot temperatures and module integrity," in Proceedings of the 26th IEEE Photovoltaic Specialists Conference, pp. 1137-1140, Anaheim, Calif, USA, October 1997.

[9] O. Breitenstein, J. P. Rakotoniaina, M. H. Al Rifai, and M. Werner, "Shunt types in crystalline silicon solar cells," Progress in Photovoltaics: Research and Applications, vol. 12, no. 7, pp. 529-538, 2004.

[10] H. Yang, W. Xu, H. Wang, and M. Narayanan, "Investigation of reverse current for crystalline silicon solar cells-new concept for a test standard about the reverse current," in 35th IEEE Photovoltaic Specialists Conference (PVSC '10), pp. 2806-2810, June 2010. 


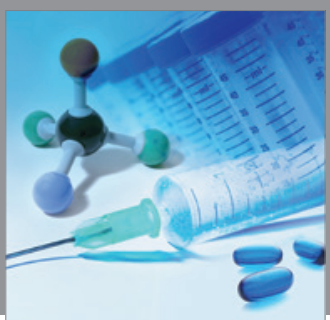

International Journal of

Medicinal Chemistry

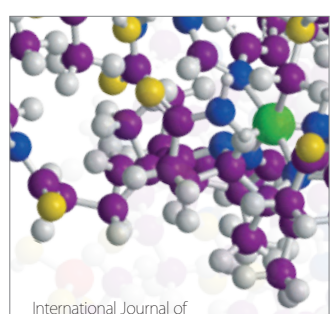

Carbohydrate Chemistry

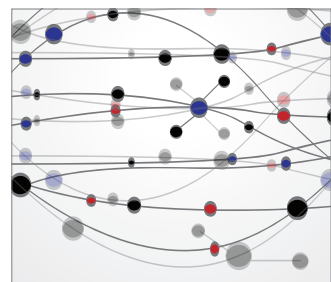

The Scientific World Journal
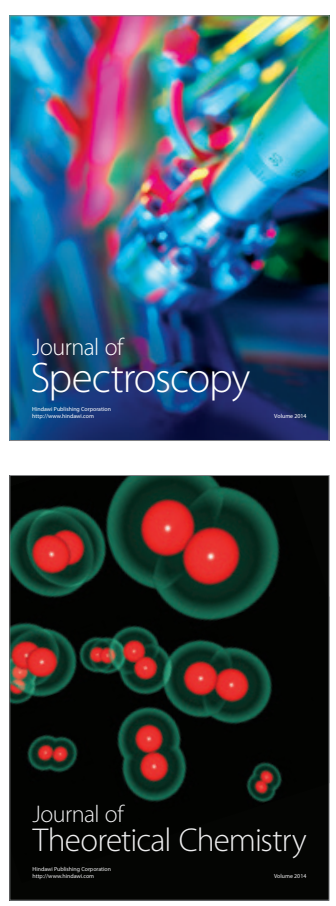
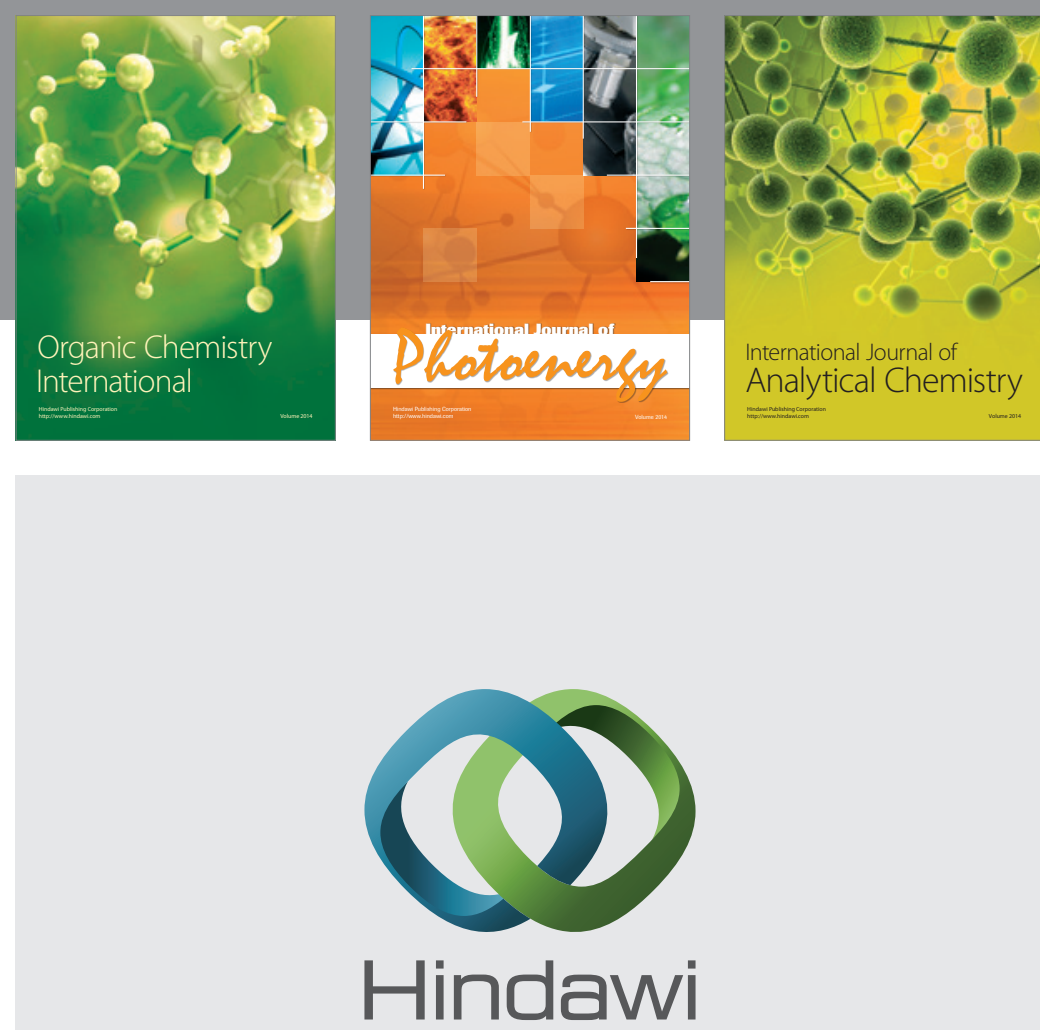

Submit your manuscripts at

http://www.hindawi.com
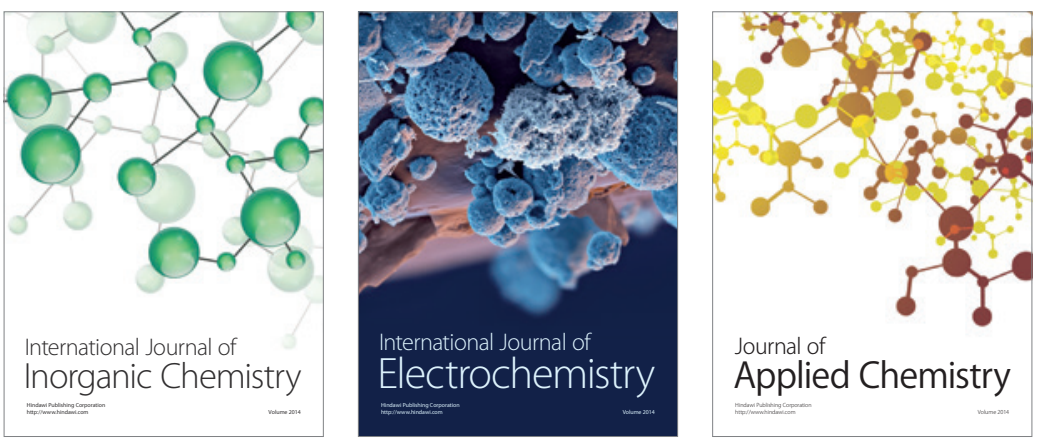

Journal of

Applied Chemistry
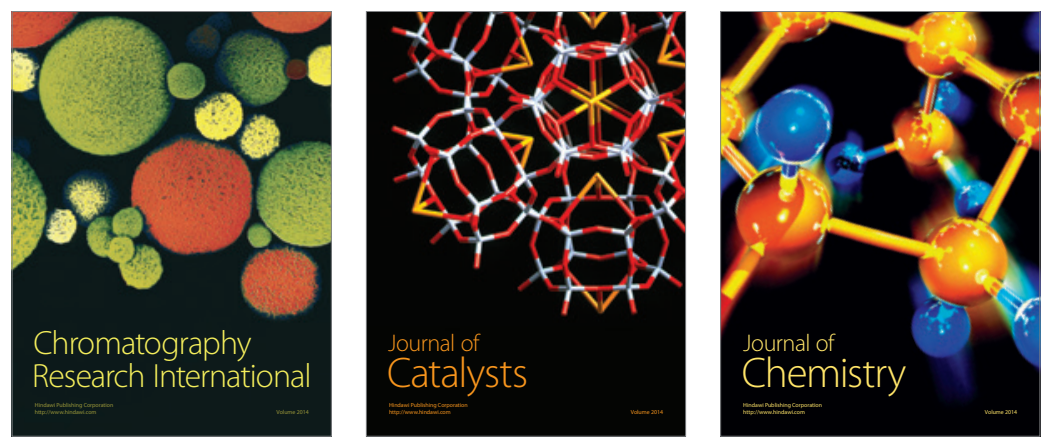
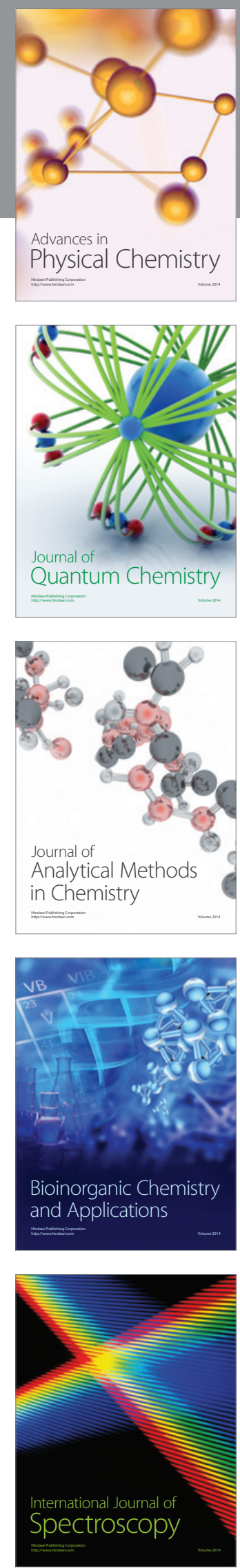